\title{
BAGAIMANA SELF-COMPASSION MEMODERASI PENGARUH MEDIA SOSIAL TERHADAP KETIDAKPUASAN TUBUH?
}

\author{
Diba Shabrina Marizka, Sri Maslihah, Anastasia Wulandari \\ Departemen Psikologi, Universitas Pendidikan Indonesia \\ E-mail:dibashabrinam@student.upi.edu,maslihah_psi@upi.edu,diangem2_psi@upi.edu
}

\begin{abstract}
This research aims to determine the influence of intensity of social media use to body dissatisfaction moderated by self-compassion among early adulthood. This research used quantitative research method with 403 early adulthood participated in this research. Instruments used were Intensitas Penggunaan Media Sosial (IPMS) to measure intensity of social media use, Multiple Body-Self Related Questionnaire Appearance Scales (MBSRQ$A S)$ to measure body dissatisfaction, and Self-Compassion Scale (SCS) to measure selfcompassion. The analysis technique used is Moderated Regression Analysis (MRA). Result show that intensity of social media use influences body dissatisfaction with a significance value 0.006. Self-compassion influences body dissatisfaction with significance value 0.000. Self-compassion moderated the influence of intensity of social media use on body dissatisfaction with significance value 0.000 .
\end{abstract}

Keywords: intensity of social media use, body dissatisfaction, self-compassion

\begin{abstract}
Abstrak
Tujuan penelitian ini adalah untuk mengetahui pengaruh intensitas penggunaan media sosial terhadap ketidakpuasan pada tubuh yang dimoderasi oleh self-compassion pada dewasa awal. Metode penelitian yang digunakan adalah metode penelitian kuantitatif dengan partisipan sebanyak 403 orang dewasa awal. Instrumen yang digunakan untuk mengukur intensitas penggunaan media sosial adalah Intensitas Penggunaan Media Sosial (IPMS), Multiple Body-Self Related Questionnaire Appearance Scales (MBSRQ-AS) untuk mengukur ketidakpuasan pada tubuh, dan Self-Compassion Scale (SCS) untuk mengukur self-compassion. Teknik analisasis yang digunakan adalah Moderated Regression Analysis (MRA). Intensitas penggunaan media sosial mempengaruhi ketidakpuasan tubuh dengan signifikansi 0.006. Self-compassion mempengaruhi ketidakpuasan tubuh dengan nilai signifikasi 0.000 . Self-compassion memoderasi pengaruh intensitas penggunaan media sosial terhadap ketidakpuasan pada tubuh dengan nilai signifikasi $0.000(\mathrm{p}<0.05)$.
\end{abstract}

Kata kunci: intensitas penggunaan media sosial, ketidakpuasan pada tubuh, selfcompassion 


\section{PENDAHULUAN}

Proses perkembangan kehidupan individu dimulai dari masa bayi, kanak-kanak, remaja, hingga dewasa. Para ahli psikologi perkembangan mengidentifikasi adanya tiga masa dalam perkembangan dewasa, yaitu dewasa awal, dewasa tengah, dan dewasa akhir (King, 2013). Tahap perkembangan dewasa awal adalah masa dimana individu berada pada rentang usia 18-40 tahun (Hurlock, 1980). Setiap tahapan perkembangan mempunyai tugasnya masing-masing. Begitupun dengan masa perkembangan dewasa awal. Menurut Hurlock (1980) masa dewasa awal adalah masa pencarian kemantapan dan masa reproduktif yaitu suatu masa yang penuh dengan masalah dan ketegangan emosional, periode isolasi sosial, periode komitmen dan masa ketergantungan, perubahan nilai-nilai, kreativitas dan penyesuaian diri pada pola hidup yang baru. Menurut Havighurts (2004), tugas perkembangan dewasa awal berkaitan langsung dengan bentuk fisik. Mencari dan menemukan calon pasangan hidup, membina kehidupan rumah tangga, dan mencari pekerjaan memerlukan daya tarik fisik yang menyebabkan mulai munculnya kebutuhan untuk memperhatikan penampilan bagi individu dalam tahap dewasa awal (Suseno, 2014). Individu pada masa dewasa awal beranggapan bahwa dengan memiliki tubuh yang ideal dan menarik, mereka akan mendapatkan kehidupan asmara yang lebih baik serta lebih mudah untuk terlibat dalam hubungan yang romantis, karena peran daya tarik fisik dalam hubungan percintaan sejak dulu telah menjadi hal yang cukup penting dan utama (Suseno, 2014). Sehingga, individu pada masa dewasa awal berusaha untuk memenuhi standar tubuh ideal menurut pandangan masyarakat (Pratiwi, 2016). Standar tubuh ideal tersebut akan membuat individu membandingkan tubuhnya sendiri dengan tubuh ideal masyarakat, sehingga munculah ketidakpuasan pada tubuh (Grogan, 1999).

Ketidakpuasan pada tubuh adalah perasaan tidak puas terhadap bentuk dan ukuran tubuh akibat dari adanya kesenjangan antara persepsi individu terhadap ukuran tubuh yang ideal dengan ukuran tubuh yang sebenarnya, atau sederhananya adalah ketidakpuasaan atas ukuran dan bentuk tubuh (Ogden, 2010). Ketidakpuasan pada tubuh merupakan komponen persepsi dari citra tubuh dikarenakan perbedaan antara tubuh ideal dan ukuran tubuh yang sebenarnya (Ogden, 2010).

Ketidakpuasan pada tubuh merupakan proses internal namun bisa dipengaruhi oleh faktor eksternal yang dapat berdampak pada bagaimana individu melihat dan merasa terkait penampilan mereka (NEDC, 2016). Salah satu dari beberapa faktor eksternal yang paling banyak ditemui menjadi penyebab berkembangnya ketidakpuasan pada tubuh adalah media (NEDC, 2016). Media adalah sesuatu yang digunakan untuk mengantar atau meneruskan informasi yang biasanya disajikan dengan menggunakan peralatan (Riyanti, 2016). Penggunaan media menjadi salah satu hal yang paling menonjol pada individu yang berada dalam masa dewasa awal (Coyne, Padilla-Walker, \& Howard, 2013). 
Kietzmann, Hermkens, McCarthy, dan Silvestre (2011) menyebutkan bahwa media sosial menawarkan banyak keuntungan, seperti kemudahan berinteraksi dan kemudahan berbagi informasi. Namun penelitian yang lebih baru menunjukkan bahwa media sosial bisa membawa dampak yang negatif, terutama terkait dengan ketidakpuasan pada tubuh (Moran, 2017). Hal tersebut bisa terjadi karena media sosial dilengkapi oleh fitur-fitur interaktif yang berbeda dari media sebelumnya dan juga memiliki pengaruh psikologis yang berbeda bagi pengguna terkait dengan citra tubuh (Fardouly \& Vartanian, 2015). Sebagian besar media sosial memuat gambar-gambar yang seringkali mempromosikan penampilan ideal yang tidak realistis, yang telah dimodifikasi oleh penata gaya dan dimanipulasi secara digital yang sebenarnya tidak bisa dicapai di kehidupan nyata (NEDC, 2016). Hal tersebut dilakukan sebagai daya tarik untuk menjual suatu produk (Irmayanti, 2009). Maka dari itu, semakin sering media mempertontonkan model-model yang berbadan kurus, maka banyak individu yang berpikir bahwa badan kurus adalah suatu keharusan agar dapat diterima oleh masyarakat (Irmayanti, 2009). Secara tidak sadar, mereka akan membandingkan diri mereka dengan apa yang mereka lihat di media (Irmayanti, 2009). Individu yang merasa bahwa dirinya tidak memenuhi standar ideal tersebut cenderung untuk mengalami ketidakpuasan pada tubuh yang dapat merusak kesejahteraan fisik dan psikologis mereka (NEDC, 2016).

Menurut Albertson, Neff, \& Dill-Shackleford (2015) ketidakpuasan pada tubuh adalah sumber utama penderitaan di kalangan wanita dari segala usia, sehingga diperlukan faktor potensial yang mampu meredakan penderitaan tersebut. Salah satu faktor potensial yang dapat meredakan penderitaan tersebut adalah self-compassion, sebuah konsep yang memiliki hubungan yang kuat dengan kesehatan psikologis (Albertson et. al, 2015). Penelitian yang dilakukan Albertson et. al (2015) menunjukkan bahwa self-compassion bisa menjadi faktor moderasi terhadap perkembangan dan intensitas persepsi negatif terkait penampilan. Self-compassion adalah pemahaman diri sendiri terhadap penderitaan, kegagalan, ataupun kesalahan dengan tidak menghakimi dan menghindar dari kekurangan, kegagalan dan ketidaksempurnaan (Neff, 2003). Selfcompassion terdiri dari tiga komponen yang saling berhubungan, yaitu self-kindness, common humanity, dan mindfulness (Neff, 2003).

Self-compassion berfungsi untuk menumbuhkan self-kindness dan perasaan sayang pada diri dan juga tubuh, serta kemampuan untuk menghadapi ancaman atau stressor dari lingkungan (salah satunya adalah tekanan dalam berpenampilan) dengan cara yang tidak menghakimi (Ferreira, Pinto-Gouveia, \& Duarte, 2013). Self-compassion membuat individu menerima tubuh sebagaimana adanya dan cenderung untuk menghindar dari perilaku mengubah bentuk tubuh (Rodgers, Donovan, Cousineau, Yates \& McGowan, 2017). Self-compassion membantu individu mengatur pikiran dan perasaan mereka untuk menerima dan tidak menghakimi terkait dengan citra tubuh, juga membantu mengurangi frekuensi individu dalam membandingkan penampilan mereka dengan orang lain (Rodgers et. al, 2017). 
Self-compassion dapat mengurangi dampak buruk dari media terkait dengan ketidakpuasan pada tubuh. Media sosial berfokus pada self-branding daripada menerima diri sendiri. Media sosial mendorong seseorang tampil sempurna untuk dinilai oleh orang lain. Harga diri seseorang dapat dengan cepat diukur dari jumlah suka, pengikut, jumlah teman, komentar alih-alih berfokus pada nilai. Sehingga individu berlomba-lomba untuk menampilkan diri sendiri lebih baik dari orang lain (Barry, Doucette, Loflin, Rivera-Hudson, Lacey, Barry \& Herrington, 2015). Self-compassion memungkinkan individu untuk tidak menghakimi diri sendiri dan tidak mengkritik diri sendiri ketika dihadapkan dengan situasi yang mengganggu di situs jejaring sosial (Neff, 2003). Individu dengan tingkat self-compassion yang lebih tinggi cenderung untuk menyadari bahwa mereka tidak sendirian dalam mengalami emosi yang memicu stres, termasuk di media sosial, dan cenderung untuk tidak memikirkan kekurangankekurangan yang mereka miliki (Neff, 2003). Self-compassion dapat mengurangi keadaan emosional yang menganggu yang dihasilkan dari penggunaan media sosial dengan meningkatkan kesadaran akan pikiran dan perasaan yang menyakitkan (Neff, 2003).

Berdasarkan penjelasan di atas peneliti tertarik untuk meneliti pengaruh intensitas penggunaan media sosial terhadap ketidakpuasan pada tubuh yang dimoderasi oleh selfcompassion pada dewasa awal.

\section{Ketidakpuasan Pada Tubuh}

Ketidakpuasan pada tubuh merupakan komponen persepsi dari citra tubuh dikarenakan adanya perbedaan antara tubuh ideal dan ukuran tubuh yang sebenarnya (Ogden, 2010). Rosen, Reiter, \& Orosan (1995) mendefinisikan ketidakpuasan pada tubuh sebagai keterpakuan pikiran akan penilaian yang negatif terhadap tampilan fisik dan adanya perasaan malu dengan keadaan fisiknya ketika berada dilingkungan sosial. Sedangkan Pruzinsky \& Cash (1990) mendefinisikan ketidakpuasan pada tubuh sebagai pikiran dan perasaan negatif seseorang mengenai tubuhnya yang meliputi ukuran tubuh, bentuk, bentuk otot, dan berat badan, dan merupakan ketidaksesuaian antara penilaian terhadap tubuh sendiri dengan tubuh ideal yang diinginkannya.

Menurut Cash (2002), ketidakpuasan pada tubuh memiliki 5 dimensi, yaitu evaluasi penampilan (apprearance evaluation), orientasi penampilan (appearance orientation), kepuasan terhadap bagian tubuh (body area satisfaction), kecemasan menjadi gemuk (overweight preoccupation), dan pengkategorian ukuran tubuh (self-classified weight). Evaluasi penampilan (apprearance evaluation) adalah perasaan individu mengenai penampilan tubuhnya, menarik atau tidak menarik, dan memuaskan atau tidak memuaskan. Orientasi penampilan (appearance orientation) adalah perhatian individu terhadap penampilan dirinya dan usaha yang dilakukan untuk memperbaiki dan meningkatkan penampilan diri. Kepuasan terhadap bagian tubuh (body area satis- 
faction) adalah kepuasan individu terhadap bagian tubuh secara spesifik, wajah, tubuh bagian atas (dada, bahu, lengan), tubuh bagian tengah (pinggang, perut), tubuh bagian bawah (pinggul, paha, pantat, kaki), serta bagian tubuh secara keseluruhan. Kecemasan menjadi gemuk (overweight preoccupation) meliputi kecemasan menjadi gemuk, kewaspadaan menjadi gemuk, kecenderungan untuk melakukan diet, dan membatasi pola makan. Sedangkan pengkategorian ukuran tubuh (self-classified weight) merefleksikan bagaimana individu menilai berat badannya, dari sangat kurus sampai gemuk.

\section{Intensitas Penggunaan Media Sosial}

Menurut Chaplin (2006) intensitas merupakan kekuatan yang mendukung suatu pendapat atau suatu sikap. Sedangkan menurut Azwar (1998) intensitas merupakan kekuatan atau kedalaman sikap terhadap sesuatu. Kemudian, menurut Santrock (2002) intensitas dapat dikatakan sebagai bentuk perhatian dan ketertarikan seseorang berdasarkan kualitas dan kuantitas yang ditunjuk individu terbebut.

Menurut Del Bario terdapat beberapa aspek yang membentuk intensitas yang berkaitan dengan media sosial (Erma, 2012), yaitu perhatian, penghayatan, durasi, dan frekuensi. Perhatian merupakan ketertarikan individu terhadap aktivitas yang sesuai dengan minatnya dan akan jauh lebih kuat dan intensif dibandingkan dengan aktivitas lain yang tidak menimbulkan minat tertentu. Penghayatan yaitu pemahaman dan penyerapan terhadap informasi dengan adanya usaha individu untuk memahami, menikmati, menghayati dan menyimpan sajian informasi maupun pengalaman yang didapat sebagai pengetahuan individu. Durasi yaitu lamanya selang waktu, rentang waktu atau lamanya sesuatu yang berlangsung. Sedangkan yang dimaksud frekuensi adalah banyaknya pengulangan perilaku atau perilaku yang dilakukan berulang-ulang baik disengaja maupun tidak disengaja.

\section{Self-compassion}

Self-compassion adalah pemahaman terhadap diri sendiri terhadap penderitaan, mengalami kegagalan, ataupun membuat kesalahan dengan tidak menghakimi dan menghindar dari kekurangan, ketidaksempurnaan, maupun kegagalan (Neff, 2003). Selfcompassion berarti terbuka dan sadar terhadap penderitaan diri sendiri, memberikan kegagalan dan ketidaksempurnaan tanpa menghakimi diri sendiri, serta melihat suatu kejadian sebagai pengalaman yang dialami semua manusia (Neff, 2003).

Self-compassion memiliki tiga komponen (Neff, 2003), yakni self-kindness vs selfjudgement, common humanity vs Isolation, dan mindfullness vs over-Identification. Self-kindness vs self-judgement adalah memahami diri sendiri saat menghadapi penderitaan daripada menghakimi dengan keras. Common humanity vs isolation adalah melihat pengalaman diri sendiri sebagai bagian dari pengalaman manusia yang umum daripada melihatnya sebagai bagian yang terpisah atau terisolasi, artinya individu memandang 
kesulitam kegagalan dan tantangan adalah bagian dari hidup manusia dan sesuatu yang dialami oleh semua orang, bukan hanya dialami oleh diri sendiri. Sedangkan mindfullness vs over-Identification adalah memberikan perhatian penuh terhadap penderitaan diri sendiri tanpa menghakiminya.

\section{METODE}

Pendekatan yang digunakan dalam penelitian ini adalah pendekatan kuantitatif dengan desain regresi moderasi. Paritisipan dalam penelitian ini adalah dewasa awal di Kota Bandung sebanyak 403 orang, yang diambil menggunakan teknik purposive sampling, yakni dengan kriteria berusia 18-40 tahun.

Instrumen yang digunakan untuk mengukur intensitas penggunaan media sosial adalah Intensitas Penggunaan Media Sosial (IPMS) yang telah disusun oleh Umi Hidayatun (2015). IPMS terdiri atas 36 item pernyataan dengan reliabilitas sebesar 0,83. Ketidakpuasan pada tubuh diukur menggunakan Multiple Body-Self Related Questionnaire Appearance Scales (MBSRQ-AS) dari Thomas F. Cash (1989). MBSRQ-AS terdiri dari 34 item dengan reliabilitas sebesar 0,78. Sedangkan untuk variabel self-compassion diukur menggunakan Self-Compassion Scale (SCS) dari Neff (2003). SCS terdiri dari 26 item dengan reliabilitas sebesar 0,90.

\section{HASIL}

Hasil analisis menunjukkan bahwa intensitas penggunaan media sosial berpengaruh secara signifikan $(0,006)$ terhadap ketidakpuasan pada tubuh dengan koefisien regresi $(0,162)$. Hal tersebut berarti bahwa ada kecenderungan semakin inten menggunakan media sosial menyebabkan semakin tidak puas pada tubuh.

\section{Tabel 1}

Efek Intensitas Penggunaan Media Sosial terhadap Ketidak Puasan Tubuh

\begin{tabular}{ccccc}
\hline & B & Sig & R & R Kuadrat \\
\hline Konstanta & 97,607 & 0,000 & & \\
$\begin{array}{c}\text { Intensitas Penggunaan } \\
\text { Media Sosial }\end{array}$ & 0,162 & 0,006 & 0,137 & 0,019 \\
\hline
\end{tabular}

Hasil analisis juga menunjukkan bahwa intensitas penggunaan media sosial dan selfcompassion memiliki pengaruh terhadap ketidakpuasan pada tubuh yang berarti compassion terhadap ketidakpuasan pada tubuh. Dua variabel prediktor memiliki efek positif, artinya semakin tinggi intensitas penggunaan media dan self compassion maka 
semakin mengalami ketidak puasan tubuh. Self-compassion memiliki koefisien sebesar 0,279 sementara intensitas memiliki koefiien $(0,172)$.

Tabel 2

Efek Intensitas Penggunaan Media Sosial dan Self-Compassion terhadap Ketidak Puasan Tubuh

\begin{tabular}{|c|c|c|c|c|}
\hline & B & Sig & $\mathbf{R}$ & R Kuadrat \\
\hline Konstanta & 71,556 & 0,000 & \multirow{3}{*}{0,298} & \multirow{3}{*}{0,089} \\
\hline $\begin{array}{c}\text { Intensitas Penggunaan } \\
\text { Media Sosial }\end{array}$ & 0,172 & 0,006 & & \\
\hline Self-compassion & 0,279 & 0,002 & & \\
\hline
\end{tabular}

Tabel 3

Efek Intensitas Penggunaan Media Sosial dan Self-Compassion terhadap Ketidak Puasan Tubuh

\begin{tabular}{|c|c|c|c|c|}
\hline & B & Sig & $\mathbf{R}$ & R Kuadrat \\
\hline Konstanta & 258,758 & 0,000 & \multirow{4}{*}{0,359} & \multirow{4}{*}{0,129} \\
\hline Intensitas Penggunaan Media Sosial & $-1,824$ & 0,000 & & \\
\hline Self-compassion & $-1,800$ & 0,000 & & \\
\hline $\begin{array}{l}\text { Intensitas Penggunaan Media Sosial*Self- } \\
\text { compassion }\end{array}$ & 0,22 & 0,000 & & \\
\hline
\end{tabular}

Hasil analisis pengaruh variabel intensitas penggunaan media sosial, selfcompassion, dan interaksi antara intensitas penggunaan media sosial dengan selfcompassion terhadap ketidakpuasan pada tubuh memliki nilai signifikan 0,000. Dua koefisien intensitas penggunaan edia sosial dan self-compassion memiliki nilai negatif artinya efek dua variabel tersebut negatif setelah ada interkasi antara variabel intensitas penggunaan media sosial dan self-compassion. Sementara itu, interaksi diantara keduanya memiliki koefisien positif yang signifikan terhadap ketidak puasan pada tubuh. 


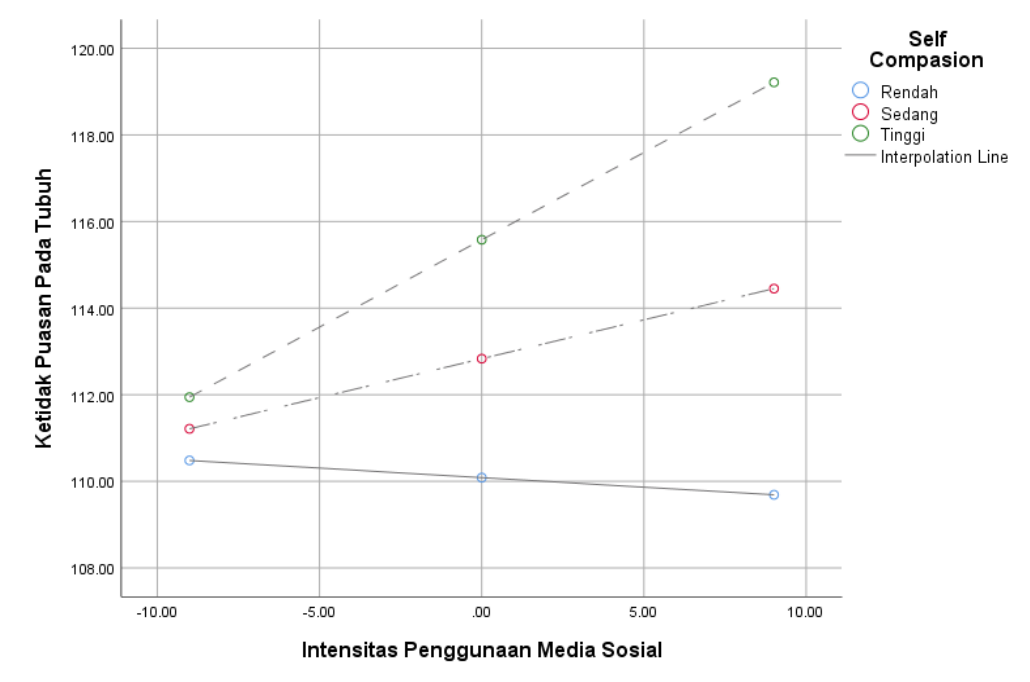

Gambar 1

Grafik Interaksi Intensitas Penggunaan Media Sosial (IPMS) dan Self-Compassion (SC) dalam Mempengaruhi Ketidak Puasan Tubuh (BD)

Interaksi pengaruh intensitas penggunaan media sosial dan self-compassion terhadap ketidakpuasan pada tubuh menunjukkan bahwa ketidak puasan pada tubuh dipengaruhi secara positif oleh intensitas penggunaan media sosial hanya terjadi pada kelompok selfcompassion tinggi dan sedang sedangkan pada kelompok self-compassion rendah. Pada kelompok tinggi (garis regresi atas) ketidakpuasan tubuh paling besar dipengaruhi oleh intensitas penggunaan media sosial daripada kelompok sedang (garis regresi tengah). Sementara pada kelompok self-compassion rendah (garis regresi bawah), orang yang memiliki intensitas penggunaan media sosial tinggi akan cenderung memiliki ketidak puasan rendah daripada yang memiliki intensitas penggunaan media sosial rendah.

\section{PEMBAHASAN}

Penelitian ini menunjukkan adanya pengaruh yang signifikan intensitas penggunaan media sosial terhadap ketidakpuasan pada tubuh. Hasil penelitian ini sejalan dengan penelitian lain yang dilakukan oleh Howard, Heron, Macintyre, Myers, \& Everharts (2017) bahwa terdapat korelasi positif antara frekuensi penggunaan media sosial dan ketidakpuasan pada tubuh pada dewasa awal. Penggunaan media sosial menciptakan pola yang maladaptif, seperti keinginan untuk diakui yang berlebihan, yang juga diasosiasikan dengan ketidakpuasan pada tubuh (Howard, 2017). Namun, hasil dari penelitian ini menunjukkan bahwa pengaruh intensitas penggunaan media sosial terhadap ketidakpuasan pada tubuh hanya sebesar 0,019 atau 1,9\%. Besaran nilai pengaruhnya dapat dikatakan kecil karena terdapat faktor-faktor lain yang memengaruhi ketidakpuasan pada tubuh sebesar 98,1\%. Selanjutnya, hasil dari penelitian ini juga 
menunjukkan bahwa self-compassion berpengaruh sebesar 8,9\% terhadap ketidakpuasan pada tubuh. Namun demikian, sama seperti pengaruh intensitas penggunaan media sosial terhadap ketidakpuasan pada tubuh sebelumnya, nilai pengaruh dari selfcompassion terhadap ketidakpuasan pada tubuh termasuk kecil karena terdapat faktorfaktor lain yang memengaruhi ketidakpuasan pada tubuh sebesar 91,1\%. Peneliti menduga, hasil penelitian tersebut disebabkan oleh karakteristik dari dewasa awal. Disebutkan oleh Hurlock (1980) bahwa karakteristik dewasa awal adalah mencari pasangan, karir, dan juga masuk ke lingkungan sosial baru. Ketiga hal ini membutuhkan sosialisasi dengan lingkungan sekitar sehingga penampilan fisik pun turut berperan.

Berdasarkan tahapan perkembangan psikososial Erikson, dewasa awal berada dalam tahap intimacy vs isolation. Tugas perkembangan pada tahap ini adalah mencari pasangan hidup untuk membangun hubungan yang serius (Papalia, Sterns, Feldman, Camp, 2002). Dewasa awal yang tidak bisa atau takut menjalin komitmen dengan orang lain akan terisolasi dan menarik diri (Prawono, 2013). Sejalan dengan karakteristik dewasa awal yang diungkapkan oleh Hurlock (2001), yaitu tugas-tugas perkembangan masa dewasa awal dipusatkan pada harapan-harapan masyarakat dan mencakup mendapatkan suatu pekerjaan, memilih seorang teman hidup, belajar hidup bersama suami/istri, membentuk suatu keluarga, membesarkan anak-anak, mengelola sebuah rumah tangga, menerima tanggung jawab sebagai warga negara dan bergabung dalam suatu kelompok sosial yang cocok. Selain itu masih menurut Hurlock (2001), bahaya fisik yang paling penting dan yang paling umum pada masa dewasa awal adalah bentuk fisik dan penampilan yang kurang menarik yang mempersulit penyesuaian diri peribadi dengan kehidupan sosial. Hal tersebut menyebabkan individu pada masa dewasa awal cenderung untuk lebih memperhatikan penampilannya, juga mengevaluasi kelebihan dan kekurangan yang ada pada tubuhnya. Jika tubuh individu tidak sesuai dengan standar ideal yang ada di masyarakat, maka ketidakpuasan pada tubuh dapat terjadi (Ogden, 2010).

Pada penelitian ini mayoritas responden berstatus lajang. Menurut penelitian yang dilakukan oleh Laus (2018) individu yang berstatus lajang lebih cenderung tidak puas terhadap tubuhnya. Hal tersebut didukung dengan data deskriptif ketidakpuasan pada tubuh dalam penelitian ini yang menunjukkan bahwa tingkat ketidakpuasan pada tubuh responden mayoritas masuk ke dalam kategori tinggi.

Seperti yang telah dipaparkan di atas, karakteristik dewasa awal cenderung membuat individu mengalami ketidakpuasan pada tubuh. Self-compassion yang diasumsikan menjadi salah satu faktor yang dapat menurunkan tingkat ketidakpuasan pada tubuh dewasa awal tidak mampu untuk menurunkan tingkat ketidakpuasan pada tubuh dewasa awal yang sudah tinggi dilihat dari tuntutan tugas perkembangannya, dan justru meningkatkan tingkat ketidakpuasan pada tubuh individu pada masa dewasa awal. Hal tersebut dapat dilihat dari hasil moderasi penelitian ini. Hasil penelitian ini 
menunjukkan bahwa interaksi antara intensitas penggunaan media sosial dan selfcompassion meningkatkan tingkat ketidakpuasan pada tubuh dewasa awal. Artinya, semakin sering individu menggunakan media sosial, dan semakin tinggi selfcompassionnya, tingkat ketidakpuasan pada tubuhnya pun akan semakin tinggi. Hasil pada penelitian ini menambah informasi mengenai pengaruh fungsi self-compassion sebagai variabel moderator antara intensitas penggunaan media sosial dengan ketidakpuasan pada tubuh. Dalam penelitian-penelitian sebelumnya menunjukkan bahwa self-compassion diindikasikan mampu untuk menurunkan tingkat ketidakpuasan pada tubuh individu namun di penelitian ini, interaksi antara intensitas penggunaan media sosial dan self-compassion justru menaikkan tingkat ketidakpuasan pada tubuh individu.

Mengakses media sosial yang memuat foto-foto kegiatan orang lain secara langsung ataupun tidak langsung membuat individu membandingkan dirinya dengan orang lain tersebut dalam segala hal termasuk penampilan (Irmayanti, 2009). Individu yang membandingkan penampilan dirinya dengan orang lain akan cenderung merasa tidak puas dengan dirinya sendiri (Irmayanti, 2009). Dibarengi oleh self-compassion yang tinggi pada dewasa awal yang sedang dalam tugas perkembangan mencapai pencapaian tinggi dalam hidup dan juga memiliki hubungan dengan lawan jenis (King, 2013), hal tersebut dapat menjadikan individu ingin mencapai yang terbaik dalam segala hal termasuk penampilan untuk menunjang tugas perkembangannya yaitu memiliki pasangan. Sehingga interaksi antara keduanya cenderung menaikkan tingkat ketidakpuasan pada tubuh individu.

\section{DAFTAR PUSTAKA}

Albertson, E. R., Neff, K. D., \& Dill-Shackleford, K. E. (2015). Self-compassion and body dissatisfaction in women: A randomized controlled trial of a brief meditation intervention. In Mindfulness (Vol. 6). https://doi.org/10.1007/s12671-014-0277-3

Andarwati, I. (2016). Citra Diri Ditinjau dari Intensitas Penggunaan Media Jejaring Sosial Instagram pada Siswa Kelas XI SMA N 9 Yogyakarta. Universitas Negeri Yogyakarta.

Andarwati, S. R., \& Sankarto, B. S. (2005). Pemenuhan Kepuasan Penggunaan Internet oleh Peneliti Badan Litbang Pertanian di Bogor. Jurnal Perpustakaan Pertanian, 14(20), 10-17.

Anggi Erma F.S. (2012). Hubungan Antara Intensitas Menonton Sinetron Televisi Terhadap Perilaku Imitasi Gaya Hidup Artis pada Remaja. Skripsi. Tidak Diterbitkan. Yogyakarta: Universitas Islam Indonesia. 
Azwar, S. (2015). Reliabilitas dan Validitas Edisi 4. Yogyakarta: Pustaka Pelajar.

Azwar. (1998). Sikap Manusia. Yogyakarta: Pustaka Pelajar.

Barry, C. T., Doucette, H., Loflin, D. C., Rivera-Hudson, N., Lacey, L., Barry, C. T., Herrington, L. L. (2015). Psychology of popular media culture "Let me take a selfie": Associations between self-photography, narcissism, and self-esteem. Psychology of Popular Media Culture. https://doi.org/10.1037/ppm0000089

Braun, T. D., Park, C. L., \& Gorin, A. (2016). Self-compassion, body image, and disordered eating: A review of the literature. Body Image, 17, 117-131. https://doi.org/10.1016/j.bodyim.2016.03.003

Budiarti, Sartika. (2017). Pengaruh Body Dissatisfaction dan Self-compassion terhadap Determinasi Diri dalam Berolahraga pada Remaja Putri di Kota Bandung. Skripsi. Tidak Diterbitkan. Fakultas Ilmu Pendidikan. Universitas Pendidikan Indonesia.

Cash, T. F., \& Fleming, E. C. (2002). The impact of body image experiences: development of the body image quality of life inventory. International Journal of Eating Disorders, 31(4), 455-460.

Cash, T. F., \& Pruzinsky, T. E. (1990). Body images: Development, deviance, and change. Guilford Press.

Chaplin, J.P. (2006). Kamus Lengkap Psikologi. Jakarta: Raja Grafindo Persada.

Coyne, S. M., Padilla-Walker, L. M., \& Howard, E. (2013). Emerging in a Digital World: A Decade Review of Media Use, Effects, and Gratifications in Emerging Adulthood. Emerging Adulthood, 1(2), 125-137. https://doi.org/10.1177/ 2167696813479782

Creswell, J. W. (2012). Educational research: planning. Conducting, and Evaluating.

Fardouly, J., Diedrichs, P. C., Vartanian, L. R., \& Halliwell, E. (2015). Social comparisons on social media: The impact of Facebook on young women's body image concerns and mood. Body Image, 13, 38-45. https://doi.org/10.1016/ j.bodyim.2014.12.002

Ferreira, C., Pinto-Gouveia, J., \& Duarte, C. (2013). Self-compassion in the face of shame and body image dissatisfaction: Implications for eating disorders. Eating Behaviors, 14(2), 207-210. https://doi.org/10.1016/j.eatbeh.2013.01.005

Fitria, E. M. (2015). Dampak Online Shop Di Instagram Dalam Shopaholic Di Samarinda. E-Jurnal Ilmu Komunikasi, 1(3), 117-128.

Gallivan, H. R. (2015). Teen Social Media \& Body Image. 
Green, S. P., \& Pritchard, M. E. (2003). Predictors of Body Image Dissatisfaction in Adult Men and Women. Social Behavior and Personality: An International Journal, 31(3), 215-222. https://doi.org/10.2224/sbp.2003.31.3.215

Griffiths, S., Murray, S. B., Krug, I., \& McLean, S. A. (2018). The Contribution of Social Media to Body Dissatisfaction, Eating Disorder Symptoms, and Anabolic Steroid Use Among Sexual Minority Men. Cyberpsychology, Behavior, and Social Networking, 21(3), 149-156. https://doi.org/10.1089/cyber.2017.0375

Grogan, S. (1999). Body image: understanding body dissatisfaction in men, women and children. New York: Taylor \& Francis e-Library.

Hapsari, I. (2009). Hubungan Faktor Personal Dan Faktor Lingkungan dengan Kecenderungan Perilaku Makan Menyimpang pada Kalangan Model di OQ Modelling School Jakarta Selatan Tahun 2009 Di Oq Modelling School Jakarta Selatan Tahun 2009. Universitas Indonesia.

Hidayatun, U. (2015). Pengaruh Intensitas Penggunaan Media Sosial dan Dukungan Teman Sebaya terhadao Perilaku Konsumtif pada Siswa Kelas XI SMA Muhammadiyah 3 Yogyakarta Tahun Pelajaran 2014/2015. Universitas Negeri Yogyakarta.

Howard, L. M., Heron, K. E., Macintyre, R. I., Myers, T. A., \& Everhart, R. S. (2017). Is use of social networking sites associated with young women's body dissatisfaction and disordered eating? A look at Black-White racial differences. Body Image, 23, 109-113. https://doi.org/10.1016/j.bodyim.2017.08.008

Irmayanti, A. (2009). Hubungan antara Media Expposure, Tingkat Ketidakpuasan terhadap Ukuran Bentuk Tubuh dan Self-esteem Remaja Puteri Jakarta. Universitas Indonesia.

Kurniawan, M. Y., Briawan, D., \& Caraka, R. E. (2015). Persepsi Tubuh dan Gangguan Makan pada Remaja. Jurnal Gizi Klinik Indonesia, 11(3), 105-114.

Laus, M. F., Almeida, S. S., \& Klos, L. A. (2018). Body image and the role of romantic relationships. Cogent Psychology, 5(1), 1-16. https://doi.org/10.1080/23311908. 2018.1496986

Liana, L. (2009). Penggunaan MRA dengan SPSS untuk Menguji Pengaruh Variabel Moderating terhadap Hubungan antara Variabel Independen dan Variabel Dependen. Jurnal Teknologi Informasi DINAMIK, 14(2), 90-97.

Moffitt, R. L., Neumann, D. L., \& Williamson, S. P. (2018). Comparing the efficacy of a brief self-esteem and self-compassion intervention for state body dissatisfaction and self-improvement motivation. Body Image, 27, 67-76. https://doi.org/ 10.1016/j.bodyim.2018.08.008 
Moran, B. (2017). Self-Compassion, Body Image Dissatisfaction, and Negative Social Comparisons in Adolescents Utilizing Social Networking Sites. Philadelphia Colleger of Osteopathic Medicine.

Murnen, S. K. (2011). Gender and body images. In T. F. Cash \& L. Smolak (Eds.), Body image: A handbook of science, practice, and prevention (pp. 173-179). New York, NY, US: Guilford Press.

NEDC. (2016). What is Body Image? In National Eating Disorders Collaboration. Retrieved from nedc.com.au/body-image

Neff, K. D., Rude, S. S., \& Kirkpatrick, K. L. (2007). An examination of selfcompassion in relation to positive psychological functioning and personality traits. Journal of Research in Personality, 41(4), 908-916. https://doi.org/10.1016/ j.jrp.2006.08.002

Neff, K. (2003). The development and validation of a scale to measure selfcompassion. Self and Identity, 2(3), 223-250. https://doi.org/10.1080/15298860390209035

Neff, Kristin. (2003). Self-Compassion: An Alternative Conceptualization of a Healthy Attitude Toward Oneself. Self and Identity, 2(2), 85-101. https://doi.org/10.1080/ 15298860309032

Nursiyono, J. A. (2015). Kompas Teknik Pengambilan Sampel. Bogor: In Media

Ogden, J. (2010). The Psychology of Eating From Healthy to Disordered Behavior (2nd ed.). West Sussex: John Wiley \& Sons.

Papalia, D. E., Sterns. H. L., Feldman, R. D., Camp, C. J. (2002). Adult Developmental and Aging. (Ed. Ke-2). New York: McGraw-Hill.

Perrin, A., Duggan, M., Rainie, L., Smith, A., Greenwood, S., Porteus, M., \& Page, D. (2015). Social media usage: 2005-2015. Pew Research Center.

Pratiwi, S. (2016). Hubungan antara Perfeksionisme dan Ketidakpuasan Terhadap Citra Tubuh pada Masa Dewasa Awal. Universitas Sanata Dharma.

Prawono, V. I. (2013). Hubungan antara Body Image Satisfaction dan Self-esteem pada Perempuan Dewasa Muda yang Berdiet di Jakarta. Psibernetika, 6(1), 39-55.

Ramadhani, D. R., Putra, D. A. ., \& Komariah, Si. H. (2017). Designing Illustrated Book about Eating Disorder For Teens. E-Proceeding of Art \& Design, 4(3), 706712. 
Rengganis, Anggi. (2015). Body Image dan Kualitas Hidup Wanita Dewasa Madya di Kota Bandung. Skripsi. Tidak DIterbitkan. Fakultas Ilmu Pendidikan. Universitas Pendidikan Indonesia

Riyanti, Y. Ak. V. (2016). Hubungan Intensitas Mengakses Sosial Media terhadap Perilaku Belajar Mata Pelajaran Produktif pada Siswa Kelas XI Jasa Boga di SMK 3 Klaten. Universitas Negeri Yogyakarta.

Rodgers, R. F., Franko, D. L., Donovan, E., Cousineau, T., Yates, K., McGowan, K., Lowy, A. S. (2017). Body image in emerging adults: The protective role of selfcompassion. Body Image, 22, 148-155. https://doi.org/10.1016/j.bodyim.2017. 07.003

Rosen, J. C., Reiter, J., \& Orosan, P. (1995). Cognitive-behavioral body image therapy for body dysmorphic disorder. Journal of Consulting and Clinical Psychology, 63(2), 263-269. https://doi.org/10.1037/0022-006X.63.3.437

Royal College of Psychiatrists. 2008: Eating Disorders. Council Report CR14. London: Author.

Santrock, J. W. (2002). Life span development: Perkembangan masa hidup. Jakarta: Erlangga, 31

Schooler, D., Ward, L. M., Merriwether, A., \& Caruthers, A. (2004). Who's that girl?: Television's role in the body image development of young White and Black women. Psychology ofWomen Quarterly, 28, 38-47.

Sigman, A. (2010). A source of thinspiration? The Biologist, 57(3).

Slater, A., Varsani, N., \& Diedrichs, P. C. (2017). \#fitspo or \#loveyourself? The impact of fitspiration and self-compassion Instagram images on women's body image, selfcompassion, and mood. Body Image, 22, 87-96. https://doi.org/10.1016/j.bodyim. 2017.06.004

Suseno, A. O., \& Dewi, K. S. (2014). Hubungan antara Ketidakpuasan Bentuk Tubuh dengan Intensi Melakukan Perawatan Tubuh pada Wanita Dewasa Awal. Empati, 3(3), 20-31.

Taqwa, M. I. (2018). Intensitas Penggunaan Media Sosial Instagram Stories pada Kesehatan Mental. Universitas Muhammadiyah Malang.

Thompson, J. K., Coovert, M. D., \& Stormer, S. M. (1999). Body image, social comparison, and eating disturbance: a covariance structure modeling investigation. Int J Eat Disord, 26(1), 43-51. Retrieved from http://www.ncbi.nlm.nih.gov/ pubmed/10349583 
Tiggemann, M. (2006). The Role of Media Exposure in Adolescent Girls' Body Dissatisfaction and Drive for Thinness: Prospective Results. Journal of Social and Clinical Psychology, 25(5), 523-541. https://doi.org/10.1521/jscp.2006.25.5.523

Tiggemann, M., \& Slater, A. (2013). NetGirls: The Internet, Facebook, and Body Image Concern in Adolescent Girls. Int J Eat Disord, 46, 630-633. https://doi.org/ 10.1002/eat.22141

Tylka, T. L., Russell, H. L., \& Neal, A. A. (2015). Eating Behaviors Self-compassion as a Moderator of Thinness-related Pressures 'Associations with Thin-ideal Internalization and Disordered eating. Eating Behaviors, 17, 23-26. https://doi.org/ 10.1016/j.eatbeh.2014.12.009

Van Vonderen, K. E., \& Kinnally, W. (2012). Media Effects on Body Image: Examining Media Exposure in the Broader Context of Internal and Other Social Factors. American Communication Journal, 14(2), 41-57. https://doi.org/10.1016/ j.bodyim.2010.07.002

Veldhuis, J., te Poel, F., Pepping, R., Konijn, E. A., \& Spekman, M. L. C. (2017). "Skinny is prettier and normal: I want to be normal" Perceived body image of nonWestern ethnic minority children in the Netherlands. Body Image, 20, 74-86. https://doi.org/10.1016/j.bodyim.2016.11.006

Woodley, A. (2018). How does Instagram impact on people's perceptions of their appearance? Journal of Aesthetic Nursing, 7(2), 94-95.

Yundarini, N. M. C. (2015). Hubungan antara Citra Tubuh dengan Perilaku Makan pada Remaja Putri. COPING (Community of Publishing in Nursing), 3(1) 